\title{
PENERAPAN KONSEP SOSIAL DAN BEHAVIOR SETTING PADA RUMAH ADAT BALI
}

\author{
Josephine Roosandriantini ${ }^{1}$, Fernanda Yosefi Meilan ${ }^{2}$ \\ 1. Dosen Program Studi Arsitektur, Fakultas Teknik, Universitas Katolik Darma Cendika \\ Jl. Dr. Ir. H. Soekarno No. 201 Surabaya \\ 2. Mahasiswa Program Studi Arsitektur, Fakultas Teknik, Universitas Katolik Darma Cendika \\ Jl. Dr. Ir. H. Soekarno No. 201 Surabaya \\ Email: josep.roo@ukdc.ac.id
}

\begin{abstract}
Abstrak
Lingkungan terbentuk secara berbeda-beda sesuai dengan aktivitas, reaksi maupun perilaku dari masing-masing individu yang tinggal di dalamnya. Pembentukan lingkungan tersebut memiliki arti arsitektural secara alamiah yang ditentukan pula oleh kebutuhan individu yang berkaitan terutama dengan kebutuhan akan pembagian sifat ruang. Pembagian sifat ruang tersebut sangat terlihat pada rumah adat Bali, yang terdiri dari ruang privat hingga ruang publik. Sifat ruang tersebut juga dipelajari dalam arsitektur perilaku, yang dalam penelitian ini yaitu pendekatan behavior setting dalam melihat hubungan sifat ruang dengan wujud fisik arsitektur Bali tersebut. Pendekatan ini juga mengamati pola perilaku pengguna yang terjadi secara berulang-ulang sehingga membentuk suatu tatanan lingkungan tersendiri. Penelitian ini dilakukan agar dapat mengidentifikasi pembagian sifat ruang dari rumah adat Bali dan pembentukan behavior setting dari pola perilaku yang terbentuk. Tujuan penelitian ini adalah untuk memahami penerapan konsep behavior setting dalam rumah adat Bali. Metode penelitian yang digunakan adalah metode deskriptif kualitatif yaitu dengan mengumpulkan data berdasarkan studi literatur mengenai arsitektur Bali. Hasil penelitian ini untuk menjelaskan kebutuhan manusia pada masing-masing setting berdasarkan sifat ruang dan juga mengetahui pembentukan konsep behavior setting dalam penataan rumah adat Bali.
\end{abstract}

Kata kunci: behavior setting, rumah adat Bali, ruang.

\begin{abstract}
Title: Application of the Social and Behavioral Setting Concept on Balinese Architecture

The neighborhood is formed unique as a result of the activities, reactions as well as behavior of the individuals who are living in it. The formation of the neighborhood has a natural architectural meaning which is determined by the necessity of individuals related to the division of the nature of space. The division of the nature of space is very apparent in Balinese traditional houses, it consists of the private to the public spaces. The nature of space is also studied in architecture behavior, and in this study behavioral approach is used in seeing the relationship between the nature of space and the physical appearance of Balinese architecture. This approach is also observing the pattern of user behavior that occurs repeatedly to form a distinct environmental order. This research was conducted to identify the spatial division and the formation of behavioral setting in which the behavior patterns is defined. The purpose of this study is to understand how the concept of behavior setting is applied in Balinese traditional houses. The research method used is a descriptive qualitative, by collecting data based on literature research on Balinese architecture. The results of this study are to explain the human needs of each arrangement based on the nature of the space, and also determine the formation of behavioral setting concepts in the arrangement of Balinese traditional houses.
\end{abstract}

Keywords: behavior settings, Bali traditional house, space. 


\section{Pendahuluan}

Individu yang tinggal dalam sebuah lingkungan, memiliki respon atau perilaku yang berbeda-beda baik secara alami maupun respon yang muncul karena stimulus dari lingkungan sekitar. Respon atau perilaku yang muncul dari individu tersebut merupakan salah satu bentuk individu dalam menciptakan kenyamanan bagi dirinya. Seperti yang dikatakan Altman (1980) bahwa terdapat hubungan timbal balik antara lingkungan dengan perilaku individu, sehingga saling mempengaruhi satu sama lain. Dalam sebuah lingkungan binaan memiliki pola ruang tersendiri, karena lingkungan merupakan wadah aktivitas dan tempat untuk melakukan kegiatan yang berulang kali dalam periode waktu tertentu. Aktivitas yang berulangulang tersebut membentuk sebuah pola aktivitas, yang menurut Barker dan Wright (1968) dikatakan sebagai behavior setting.

Behavior setting menurut Edward Hall (1966) dalam Laurens (2004) terdapat tiga pola ruang, yaitu ruang berbatas tetap (fixedfeature space), ruang berbatas semitetap (semifixed-feature space) dan ruang informal. Selain itu, behavior setting merupakan suatu kombinasi yang stabil antara aktivitas, tempat, periode waktu yang berulang-ulang. Sebuah ruang dapat dikatakan sebagai sebuah behavior setting jika aktivitas dalam suatu ruang terjadi secara berulang-ulang dalam periode waktu tertentu sehingga membentuk pola aktivitas/ perilaku (standing patern of behavior).

Seperti pada rumah adat Bali, dalam satu kavling terdiri lebih dari satu bangunan yang memiliki fungsi aktivitas yang berbedabeda. Setiap massa bangunan dalam rumah tradisional Bali memiliki pola aktivitas yang berulang-ulang yang terjadi dalam kesehariannya, sehingga rumah adat Bali dapat dikatakan sebagai behavior setting. Oleh karena itu, penelitian ini menggunakan rumah adat Bali yang bentuk rumahnya merupakan satu kavling terdiri dari beberapa masa atau bangunan. Penelitian ini menggunakan data mengenai rumah adat Bali pada umumnya dan juga merujuk pada rumah tinggal di Desa Tenganan Pagrisingan (Runa, 2018).

Konsep sosial yang berkaitan dengan behavior setting antara lain tentang teritorialitas, personal space dan privacy. Jika membahas tiga konsep sosial tersebut maka akan terkait dengan sebuah batas secara arsitektural, baik nyata maupun semu yang bertujuan untuk membagi tiap ruang menurut fungsi maupun untuk memberikan sifat terhadap ruang itu sendiri. Sifat ruang seperti halnya ruang privat, ruang semiprivat, ruang publik dan ruang semipublik.

Pengaruh ruang terhadap perilaku individu adalah fungsi atau pemakaian ruang tersebut. Secara sederhana, Sommer dalam Halim (2005) mengatakan bahwa ruang pribadi (personal space) merupakan batas yang tidak secara jelas tampak di sekitar seseorang yang membuat orang lain merasa enggan untuk memasukinya. Personal space juga menyangkut pembahasan tentang teritorialitas dan privacy, yang sangat berkaitan erat dengan bidang-bidang pembentuk ruang. Ruang merupakan sebuah komponen utama dalam membahas hubungan antara arsitektur dengan perilaku individu di dalamnya, berkaitan dengan fungsi ruang tersebut. Laurens (2004) menyatakan bahwa teritorial merupakan hubungan antara pola tingkah laku dengan hak kepemilikan seseorang atau kelompok terhadap suatu tempat. Jika sebuah teritori tersebut diganggu maka akan menimbulkan ketidaknyamanan dari individu yang menempatinya. Begitu juga privasi, Lang (1987) menyatakan bahwa tingkat dari privasi tergantung pada pola perilaku dalam konteks budaya dan kepribadian serta keterlibatan individu. 
Komponen-komponen yang dapat membentuk konsep sosial behavior setting dalam sebuah ruang yaitu yang bersifat fix (tetap) seperti dinding, kolom dan atap, semi-fix (agak tetap) seperti perabot ataupun yang bersifat non-fix (tidak tetap) seperti warna dan dekorasi. Penelitian ini untuk menganalisis rumah adat Bali yang tiap rumahnya terdiri dari beberapa masa dengan dibatasi tembok yang mengelilingi rumah tersebut. Tujuan dari penelitian ini adalah untuk mengetahui apakah rumah adat Bali dapat dikatakan sebagai behavior setting dan bagaimana cara menerapkan konsep sosial behavior setting dalam penataan ruangnya. Dengan demikian, penelitian ini dapat menambah pemahaman bahwa arsitektur nusantara juga dapat menerapkan konsep sosial menurut teori psikologi lingkungan seperti behavior setting.

\section{Metode Penelitian}

Metode yang digunakan dalam penelitian ini adalah metode deskriptif kualitatif. Pada penelitian ini dilakukan penggumpulan data, analisis data dan pembahasan yang tercantum dalam latar belakang pada bagian pendahuluan.

\section{Metode Penggumpulan Data}

Metode penggumpulan data ini dilakukan dengan cara studi literatur (literature research), yaitu mengumpulkan data berdasarkan buku, jurnal, artikel yang terkait dengan konsep behavior setting, penataan rumah adat Bali dan konsep sosial dari rumah adat Bali.

\section{Metode Analisis Data}

Metode analisis data ini dilakukan dengan memilih data literatur yang tersedia dan disesuaikan dengan topik permasalahan penelitian ini. Selain itu, dalam penyajian data dilakukan dengan membuat laporan hasil penelitian dalam menyusun konsep yang telah diteliti/ dianalisis untuk dapat lebih mudah dipahami dan dapat untuk mencapai tujuan yang diinginkan oleh penelitian ini. Tahapan terakhir adalah menarik kesimpulan dari analisis yang telah dilakukan.

\section{Hasil dan Pembahasan}

Pendekatan Arsitektur Psikologi dengan konsep behavior setting adalah sebuah konsep tata perilaku yang berada dalam sebuah bangunan yang memiliki aktivitas berulang di dalamnya. Rumah adat Bali merupakan satu kavling dengan terdiri dari beberapa massa bangunan yang memiliki fungsi dan aktivitas yang beranekaragam. Mulai dari yang berfungsi sebagai tempat pemujaan kepada Sang Hyang Widhi hingga pawon (dapur). Denah satu kavling rumah adat Bali tergambarkan sebagai berikut:

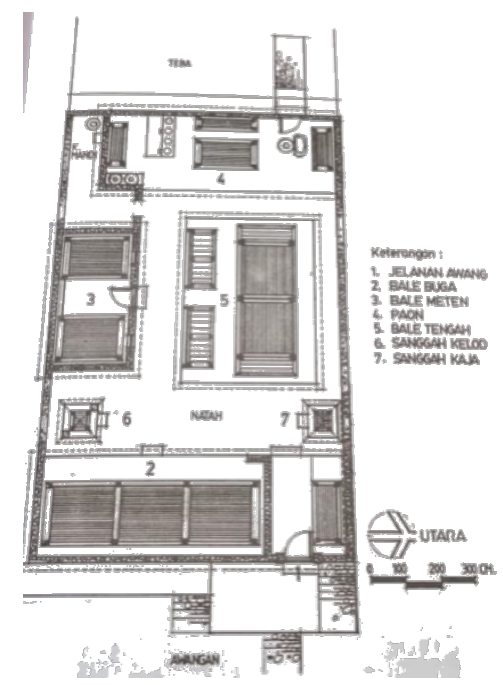

Gambar 1. Struktur spasial rumah tinggal desa Tenganan Pagrisingan Sumber: Runa, 2018

Konsep sosial yang berkaitan dengan behavior setting antara lain tentang teritorialitas, personal space dan privacy. Konsep sosial yang merupakan konsep 'Barat' tersebut ternyata juga dapat terlihat dalam rumah adat Bali, yaitu sebagai berikut:

\section{Teritorialitas}

Rumah adat Bali merupakan satu kavling dengan beberapa massa bangunan dan fungsi yang berbeda-beda. Kavling tersebut 
dikelilingi oleh tembok sehingga dapat menggambarkan sebuah teritori/ kepemilikan yang sangat privat. Pembatasan tersebut juga merupakan sebuah cara untuk membatasi hubungan interpersonal dengan pihak luar/ orang lain.

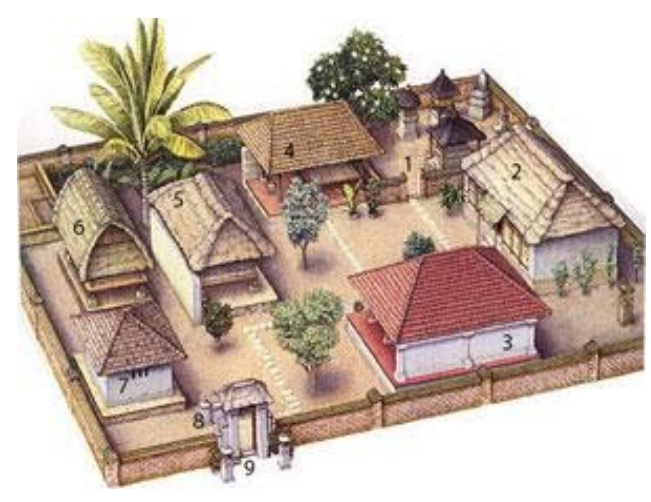

Gambar 2. Kavling rumah adat Bali Sumber: Purwestri, 2015

Menurut Altman (1975) dalam Halim (2005), teritori dibagi menjadi tiga bagian yaitu:

\section{Primary Territory}

Rasa kepemilikan tingkat tinggi, sehingga hanya orang tertentu yang memiliki akses ruang tersebut. Dalam rumah adat Bali ini yang termasuk dalam primary territory adalah satu kavling rumah itu sendiri, sebab jika ingin memasuki rumah tersebut harus melalui pintu keluar masuk (jelanan awang atau kori ngeleb).

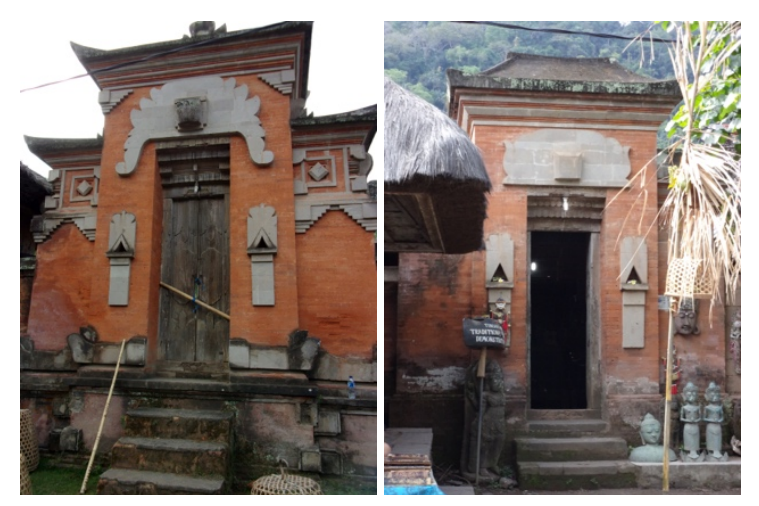

Gambar 3. Jelanan awang (kori ngeleb) pintu keluar masuk rumah adat Bali Sumber : Dokumentasi pribadi
2. Secondary Territory

Rasa kepemilikan tingkat sedang, sehingga hanya seseorang atau kelompok tertentu yang memiliki akses pada periode waktu tertentu. Sehingga, kepemilikan ruang tersebut dapat berganti orang, tergantung periode waktu tertentu. Jika dilihat pada rumah adat Bali maka secondary territory yaitu Bale Buga dan Bale Meten. Bale Buga yang memiliki fungsi sebagai tempat upacara, khususnya upacara yang berhubungan dengan kegiatan adat seperti upacara daur hidup dan tempat tidur orang tua lanjut usia. Sedangkan Bale Meten berfungsi sebagai tempat tidur dan tempat menyimpan barang berharga.

Selain itu, Bale Dangin berfungsi untuk tempat upacara adat. Namun, jika tidak digunakan maka hanya digunkan untuk tempat beristirahat. Bagian ini terletak di daerah timur. Bale Dangin masuk ke dalam ruang semi publik atau secondary territory.

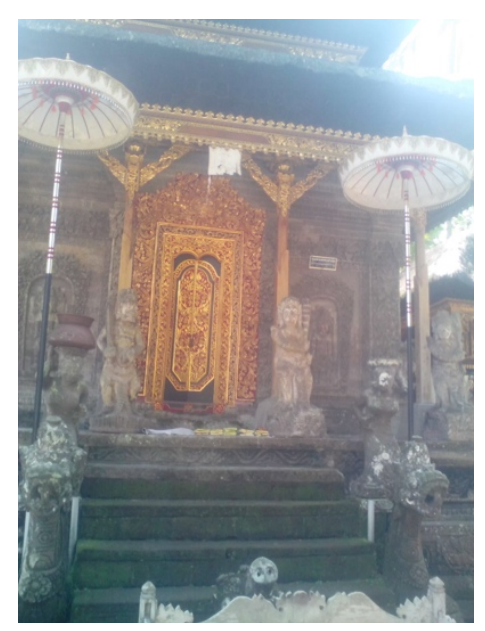

Gambar 4. Bale Meten Sumber: Dokumentasi pribadi 


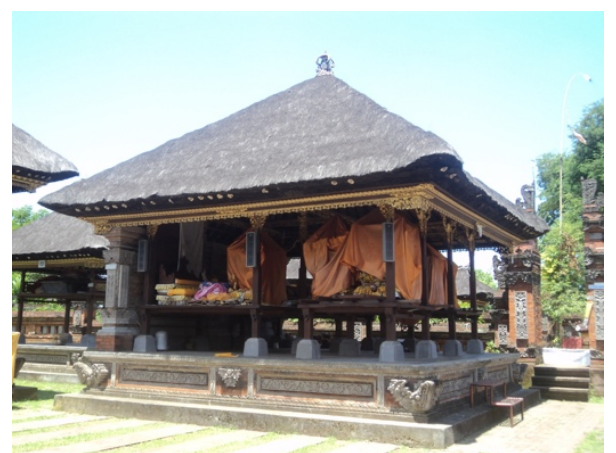

Gambar 5. Bale Dangin

Sumber: Dokumentasi pribadi

\section{Public Territory}

Ruang yang tidak dimiliki oleh seseorang atau kelompok tertentu, sehingga rasa kepemilikan ruang publik ini sangat rendah. Area tersebut dapat digunakan oleh sebanyak mungkin orang dan memiliki hak yang sama terhadap ruang tersebut. Dalam kavling rumah adat Bali, ruangan yang termasuk dalam public territory ini adalah bagian paon (dapur) dan natah. Natah merupakan ruang yang berada di tengah yang dikelilingi oleh massa - massa bangunan untuk pusat sirkulasi. Natah juga berfungsi sebagai ruang tamu (Windhu, 1985).

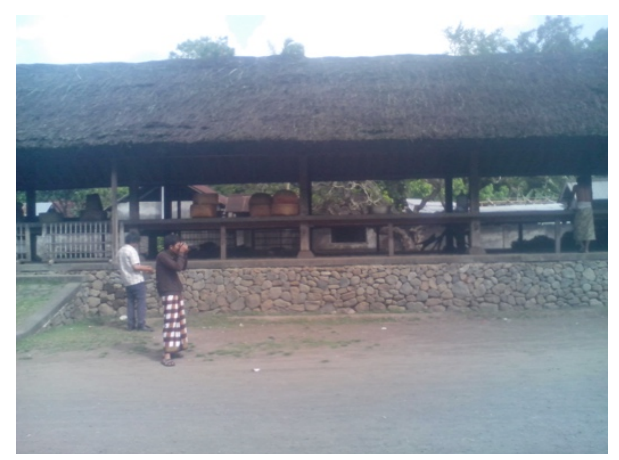

Gambar 6. Paon (dapur)

Sumber: Dokumentasi pribadi

\section{Personal Space}

Personal space lebih bersifat pribadi dan cenderung tidak memiliki batas/ pembatas yang nyata (bersifat semu). Tetapi jika ruang tersebut tanpa batas yang nyata, jika area tersebut dimasuki oleh orang lain atau kelompok lain, maka ada rasa terganggu dan tidak nyaman bagi yang memiliki ruang tersebut. Dalam kavling rumah adat Bali ini yang termasuk personal space adalah Sanggah Kelod yaitu sebagai media pemujaan leluhur dan Tuhan (Runa, 2018).

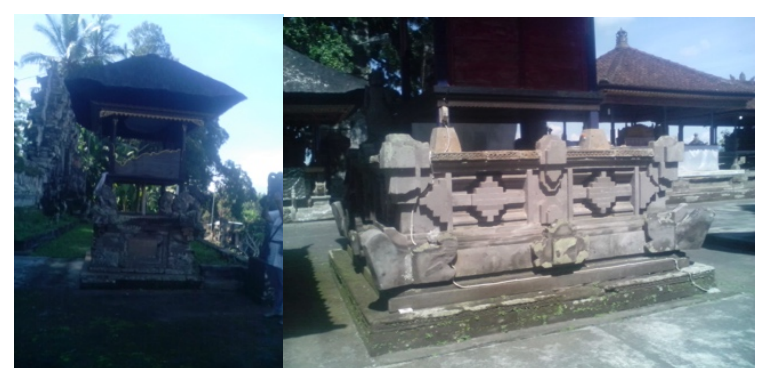

\section{Gambar 7. Sanggah Kelod (tempat pemujaan)}

Sumber: Dokumentasi pribadi

\section{Privacy}

Privacy merupakan suatu keinginan seseorang dalam membatasi diri dari orang lain diluar dirinya dan juga lingkungan sekitar (Laurens, 2004). Jika dianalisis, rumah adat Bali memiliki tingkat privasi cukup tinggi sebab area rumah dibatasi oleh tembok keliling (tembok penyengker) sehingga terbatasi antara hubungan interpersonal dengan orang sekitar.

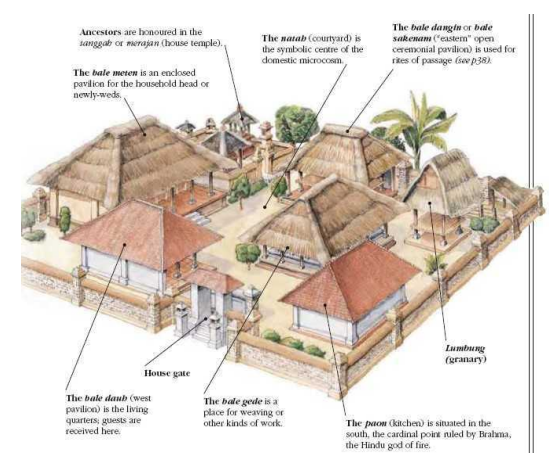

Gambar 8. Pembagian fungsi dalam satu kavling rumah adat Bali

Sumber: Purwestri, 2015

Analisis berdasarkan konsep sosial di atas juga dapat didukung dengan pengamatan tentang behavior setting. Menurut Altman (1980), elemen penanda teritori dalam membentuk ruang dibagi menjadi batas 
fisik/ tetap, batas semi tetap dan batas publik. Dalam satu kavling rumah adat Bali terdiri dari beberapa unit pavilion dan masing-masing memiliki batas fisik yang beraneka ragam sesuai fungsinya.

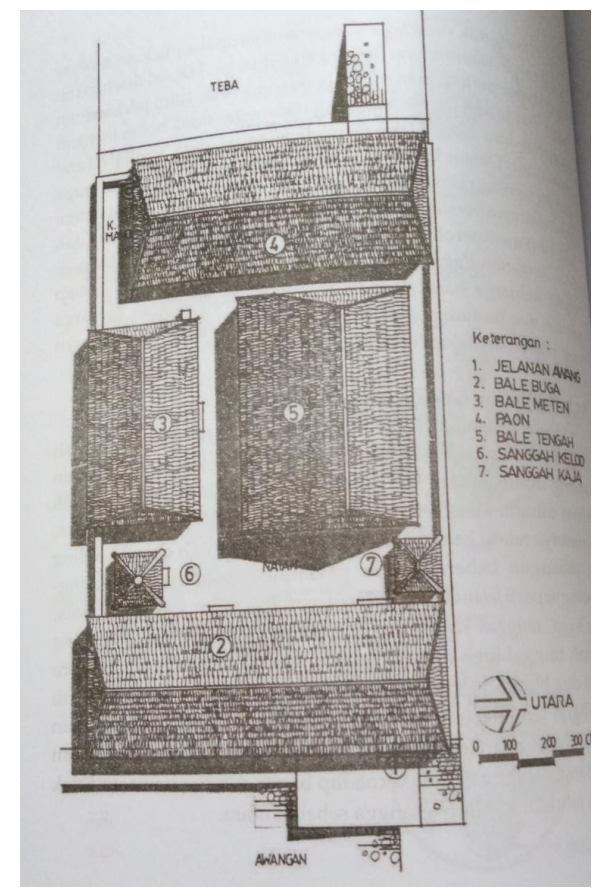

Gambar 9. Peruangan rumah tinggal standar di desa Pagringsingan Sumber: Runa, 2018:140

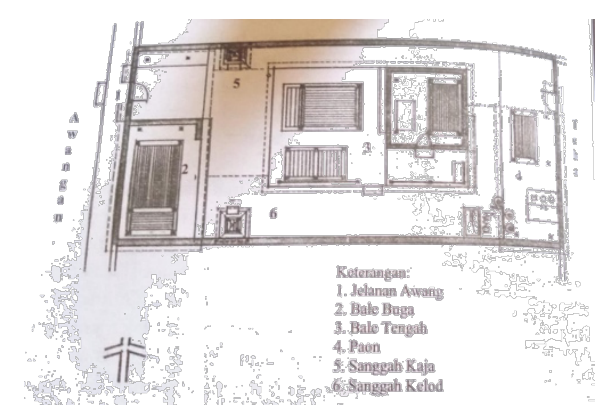

Gambar 10. Peruangan rumah tinggal kecil Sumber: Runa, 2018:142

Dalam gambar 9 pada rumah tinggal desa Tenganan Pagringsingan dapat dilihat denah rumah adat Bali memiliki berbagai fungsi dan memiliki batas fisik sesuai dengan sifat ruang tersebut, yaitu sebagai berikut (Runa, 2018:140-141):
1. Jelanan awang/ kori ngeleb sebagai pintu keluar masuk kavling rumah adat Bali, sehingga memiliki batas tetap/ nyata secara fisik berupa tembok penyengker mengelilingi unit-unit pavilion.

2. Bale Buga berfungsi sebagai tempat upacara dan tempat tidur orang tua lanjut usia. Berdasarkan gambar 10, secara garis besar tiap unit pavilion rumah adat Bali tersebut tidak memiliki dinding pembatas nyata/ massif. Pembatas secara semu yang didasarkan pada fungsi massa bangunan tersebut yang menggambarkan sifat ruang tersebut. Bale Buga dapat dijadikan sebagai area publik (tempat upacara) dan juga dapat dijadikan sebagai area privat (tempat tidur orang yang sudah lanjut usia).

3. Sanggah Kelod berfungsi sebagai tempat memuja roh leluhur dan Tuhan.

4. Sanggah Kaja berfungsi sebagai media pemujaan Betara dari Ngis (Dewa Gede Dangin). Area untuk tempat pemujaan Betara dan memuja roh leluhur dan Tuhan merupakan tempat yang bersifat sakral/ privat karena berkaitan dengan kehidupan antara penghuni rumah dengan sang pencipta. Walaupun pada gambar 10 tidak terdapat tembok atau pembatas secara fisik pada Sanggah Kelod dan Sanggah Kaja, tetapi menurut fungsinya yang sakral itu menjadikan area tersebut bersifat privat. Sehingga, jika ada orang yang sedang sembahyang di Sanggah tersebut, tidak ada yang dapat memasuki area tersebut dengan sesuka hati.

5. Bale Tengah berfungsi untuk upacara kelahiran dan upacara kematian. Upacara kelahiran dan kematian dapat diakses oleh semua orang, tetapi yang masih kerabat dari pemilik rumah. Sehingga, jika ada acara upacara kelahiran maka area Bale Tengah dapat diakses oleh banyak tamu yang hadir. Dengan demikian, dapat dikatakan sebagai area publik.

6. Bale Meten berfungsi sebagai tempat tidur dan tempat menyimpan barang 
berharga. Bale Meten ini dapat dikatakan sebagai ruang privat karena merupakan ruang pribadi yang hanya dapat diakses oleh individu yang memiliki ruang tersebut. Jika ruang privat tersebut tidak dapat dipertahankan keprivatannya maka akan menyebabkan masalah sosial. Selain itu, fungsi dari Bale Meten adalah untuk tempat tidur dan menyimpan barang berharga.

7. Paon sebagai tempat memasak dan menumbuk padi. Bagian paon atau dapur ini merupakan area publik yang ada di unit pavilion rumah adat Bali. Area paon ini juga tidak memiliki penutup/ pembatas berbentuk fisik. Oleh karena itu, area ini digunakan oleh orang banyak/ semua penghuni rumah dapat mengakses paon ini dan melakukan aktivitas (memasak) secara bersamasama.

Berdasarkan pembahasan yang telah dilakukan, maka didapatkan hasil bahwa rumah tradisional Bali ini menerapkan konsep sosial dalam satu kavling rumah tersebut, yaitu dapat diperjelas dalam tabel berikut ini:

Tabel 1. Analisis penerapan konsep sosial pada tiap bagian rumah adat Bali

\begin{tabular}{|l|l|l|l|}
\hline No. & \multicolumn{1}{|c|}{$\begin{array}{c}\text { Nama } \\
\text { Bagian } \\
\text { Rumah Bali }\end{array}$} & \multicolumn{1}{|c|}{ Fungsi } & \multicolumn{1}{c|}{$\begin{array}{c}\text { Konsep } \\
\text { Sosial }\end{array}$} \\
\hline 1. & $\begin{array}{l}\text { Jelanan } \\
\text { Awang/ Kori } \\
\text { Ngeleb }\end{array}$ & $\begin{array}{l}\text { Pintu keluar } \\
\text { masuk } \\
\text { kavling } \\
\text { rumah adat } \\
\text { Bali }\end{array}$ & $\begin{array}{l}\text { Penanda } \\
\text { teritori/ } \\
\text { ruang privat }\end{array}$ \\
\hline 2. & Bale Buga & $\begin{array}{l}\text { Tempat dan } \\
\text { upacara dan } \\
\text { tempat tidur } \\
\text { orang tua } \\
\text { lanjut usia }\end{array}$ & $\begin{array}{l}\text { a. Ruang } \\
\text { privat saat } \\
\text { jadi ruang } \\
\text { tidur } \\
\text { b. Ruang } \\
\text { publik saat } \\
\text { jadi tempat } \\
\text { upacara }\end{array}$ \\
\hline 3. & $\begin{array}{l}\text { Sanggah } \\
\text { Kelod }\end{array}$ & $\begin{array}{l}\text { Tempat } \\
\text { memuja roh } \\
\text { leluhur dan } \\
\text { Tuhan }\end{array}$ & $\begin{array}{l}\text { Ruang } \\
\text { privat/ sakral }\end{array}$ \\
\hline
\end{tabular}

\begin{tabular}{|c|c|c|c|}
\hline 4. & $\begin{array}{l}\text { Sanggah } \\
\text { Kaja }\end{array}$ & $\begin{array}{l}\text { Media } \\
\text { pemujaan } \\
\text { Betara dari } \\
\text { Ngis }\end{array}$ & $\begin{array}{l}\text { Ruang } \\
\text { privat/ sakral }\end{array}$ \\
\hline 5. & Bale Tengah & $\begin{array}{l}\text { Upacara } \\
\text { kelahiran } \\
\text { dan upacara } \\
\text { kematian }\end{array}$ & $\begin{array}{l}\text { Ruang } \\
\text { bersifat } \\
\text { semipublik/ } \\
\text { semiprivat } \\
\text { (kerabat saja } \\
\text { yang boleh } \\
\text { mengakses) }\end{array}$ \\
\hline 6. & Bale Meten & $\begin{array}{l}\text { Tempat tidur } \\
\text { dan tempat } \\
\text { menyimpan } \\
\text { barang } \\
\text { berharga }\end{array}$ & Ruang privat \\
\hline 7. & Paon & $\begin{array}{l}\text { Tempat } \\
\text { memasak } \\
\text { dan } \\
\text { menumbuk } \\
\text { padi }\end{array}$ & $\begin{array}{l}\text { Ruang publik } \\
\text { (boleh } \\
\text { diakses } \\
\text { banyak } \\
\text { orang) }\end{array}$ \\
\hline
\end{tabular}

Sumber: Hasil analisis

Berdasarkan pembahasan maka didapatkan hasil bahwa rumah tradisional Bali ini menerapkan konsep behavior setting yang dilihat berdasarkan periode waktu atau penggunaan aktivitas yang berulang pada tiap ruang, yaitu dapat diperjelas dalam tabel berikut ini:

Tabel 2. Analisis penerapan behavior setting yang berkaitan dengan periode waktu dan pola aktivitas

\begin{tabular}{|c|c|c|c|}
\hline No. & $\begin{array}{l}\text { Nama } \\
\text { Ruang }\end{array}$ & $\begin{array}{l}\text { Periode } \\
\text { Waktu }\end{array}$ & Pola Aktivitas \\
\hline 1. & $\begin{array}{l}\text { Jelanan } \\
\text { Awang/ } \\
\text { Kori } \\
\text { Ngeleb }\end{array}$ & \begin{tabular}{lr} 
Setiap & saat \\
untuk & keluar \\
masuk & rumah \\
\multicolumn{2}{c}{ adat Bali }
\end{tabular} & $\begin{array}{l}\text { Perilaku } \\
\text { pemilik rumah } \\
\text { atau tamu yang } \\
\text { ingin masuk } \\
\text { atau keluar } \\
\text { rumah induk }\end{array}$ \\
\hline 2. & Bale Buga & $\begin{array}{l}\text { a. Jika ada } \\
\text { upacara } \\
\text { saja } \\
\text { digunakan } \\
\text { b. Selalu } \\
\text { digunakan } \\
\text { setiap hari } \\
\text { sebagai } \\
\text { tempat } \\
\text { tidur orang } \\
\text { tua lanjut } \\
\text { usia }\end{array}$ & $\begin{array}{l}\text { a. Ruang } \\
\text { digunakan } \\
\text { sebagai } \\
\text { tempat tidur } \\
\text { maka perilaku } \\
\text { monoton yaitu } \\
\text { untuk tidur } 8 \text { - } \\
10 \text { jam sehari } \\
\text { b.Ruang } \\
\text { digunakan } \\
\text { sebagai } \\
\text { upacara maka }\end{array}$ \\
\hline
\end{tabular}




\begin{tabular}{|c|c|c|c|}
\hline & & & $\begin{array}{l}\text { perilaku yang } \\
\text { dilakukan } \\
\text { berjalan, } \\
\text { berfoto dan } \\
\text { krgiatan } \\
\text { upacara adat }\end{array}$ \\
\hline 3. & $\begin{array}{l}\text { Sanggah } \\
\text { Kelod }\end{array}$ & $\begin{array}{l}\text { Digunakan } \\
\text { saat sedang } \\
\text { berdoa atau } \\
\text { menaruh } \\
\text { sesaji } \\
\text { (sewaktu- } \\
\text { waktu) }\end{array}$ & $\begin{array}{l}\text { Perilaku } \\
\text { berjalan menuju } \\
\text { ke tempat untuk } \\
\text { meletakkan } \\
\text { sesaji }\end{array}$ \\
\hline 4. & $\begin{array}{l}\text { Sanggah } \\
\text { Kaja }\end{array}$ & $\begin{array}{l}\text { Digunakan } \\
\text { saat sedang } \\
\text { berdoa atau } \\
\text { menaruh } \\
\text { sesaji } \\
\text { (sewaktu- } \\
\text { waktu) }\end{array}$ & $\begin{array}{l}\text { Perilaku } \\
\text { berjalan menuju } \\
\text { ke tempat untuk } \\
\text { meletakkan } \\
\text { sesaji }\end{array}$ \\
\hline 5. & $\begin{array}{l}\text { Bale } \\
\text { Tengah }\end{array}$ & $\begin{array}{l}\text { Digunakan } \\
\text { saat kelahiran } \\
\text { dan kematian } \\
\text { dan dihadiri } \\
\text { oleh orang } \\
\text { banyak yang } \\
\text { masih kerabat } \\
\text { pemilik rumah }\end{array}$ & $\begin{array}{l}\text { Ruang } \\
\text { digunakan } \\
\text { sebagai tempat } \\
\text { upacara } \\
\text { kelahiran dan } \\
\text { kematian, } \\
\text { perilaku yang } \\
\text { dilakukan } \\
\text { berjalan, } \\
\text { berfoto, dan } \\
\text { kegiatan } \\
\text { upacara adat }\end{array}$ \\
\hline 6. & Bale Meten & $\begin{array}{l}\text { Digunakan } \\
\text { hampir setiap } \\
\text { hari }\end{array}$ & $\begin{array}{l}\text { a. Aktivitas } \\
\text { menaruh } \\
\text { barang } \\
\text { berharga saja } \\
\text { b. Perilaku } \\
\text { monoton } \\
\text { yaitu untuk } \\
\text { tidur } 8-10 \\
\text { jam sehari }\end{array}$ \\
\hline 7. & Paon & $\begin{array}{l}\text { Digunakan } \\
\text { hampir setiap } \\
\text { hari }\end{array}$ & $\begin{array}{l}\text { Perilaku yang } \\
\text { dilakukan } \\
\text { hampir setiap } \\
\text { hari (pagi, siang } \\
\text { dan sore) untuk } \\
\text { menyiapkan } \\
\text { masakan. }\end{array}$ \\
\hline
\end{tabular}

Sumber: Hasil analisis

Berdasarkan hasil analisis yang dilakukan terkait penerapan konsep sosial dan behavior setting berkaitan dengan periode waktu dan aktivitas yang dilakukan, maka didapatkan hasil bahwa rumah adat Bali merupakan salah satu wujud penerapan konsep sosial dan behavior setting. Jika digambarkan dalam skema, berawal dari aktivitas/ fungsi ruang, yang berlangsung dengan periode waktu tertentu dan dapat membentuk sifat ruang, yaitu sebagai berikut:

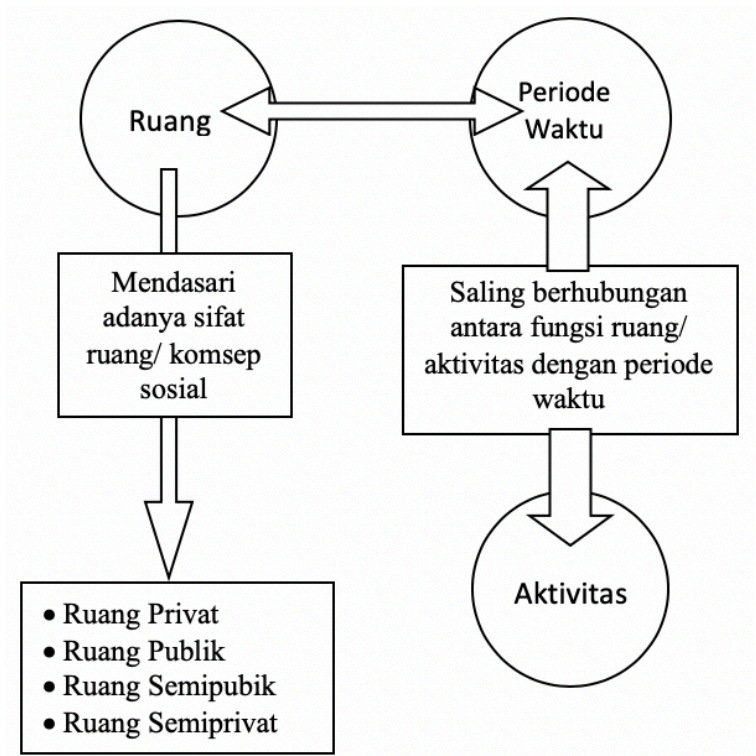

Gambar 11. Skema penggambaran hubungan antara aktivitas, periode waktu, dan sifat ruang/ konsep sosial

Sumber: Hasil analisis

Skema penggambaran hubungan antara aktivitas, periode waktu dan sifat ruang/ konsep sosial ini merupakan sebuah analisis bahwa terjadi aktivitas atau fungsi yang beranekaragam pada setiap massa bangunan di dalam kavling rumah adat Bali, yang setiap aktivitasnya memiliki periode waktu tertentu dan dilakukan secara berulangulang. Aktivitas/ fungsi yang bervariasi tersebut secara tidak langsung diwadahi oleh sebuah ruang yang berbeda-beda. Oleh karena ruang tersebut memiliki fungsi mulai sakral/ privat hingga berskala publik, sehingga aktivitas tersebut dapat membentuk sifat ruang terhadap masing-masing bagian ruang pada rumah adat Bali (Tabel 1). 


\section{Kesimpulan}

Berdasarkan analisis yang dilakukan dapat disimpulkan bahwa rumah adat Bali menerapkan konsep behavior setting. Dalam rumah adat Bali dapat terlihat pembagian ruang berdasarkan skala privat, semi privat maupun publik. Sehingga, dengan adanya pembagian ruang berdasarkan sifatnya tersebut membuat penghuni rumah maupun tamu dapat menyesuaikan sikap dan perilaku saat berada di ruang tersebut (secara sosial). Selain itu, juga dapat membuat orang asing dapat menghargai teritori setiap orang yang ditandai dengan tembok penyengker tersebut (secara lingkungan).

\section{Ucapan Terima Kasih}

Terima kasih kepada rekan sejawat dan mahasiswa yang membantu memberikan informasi/ data dan bekerja sama untuk penelitian ini, serta semua pihak yang tidak dapat saya sebutkan satu-persatu. Sehingga, penelitian ini dapat tersusun dan dapat terselesaikan, walaupun masih banyak kekurangan.

\section{Daftar Pustaka/ Referensi}

Altman, I. dan Chemers, M. (1980). Culture and environment. Monterey, Ca.: Brooks/Cole.

Barker, R. (1968). Ecological psychology: Concepts and methods for studying the environment of human behavior. Stanford, California: Stanford University Press.

Halim, D. (2005). Psikologi arsitektur: Pengantar kajian lintas disiplin. Jakarta: PT. Grasindo.

Lang, J. (1987). Creating architectural theory. New York: Van Nostrand Reinhold Inc.

Laurens, J.M. (2004). Arsitektur dan perilaku manusia. Jakarta: PT. Gramedia Widiasarana Indonesia bekerja sama dengan Universitas Kristen Petra Surabaya.

Purwestri, N., dkk. (2015). Atlas arsitektur tradisional Indonesia seri 2 (Sulawesi, Bali dan Kalimantan). Jakarta: Direktorat Sejarah dan Nilai Budaya Kementerian Pendidikan dan Kebudayaan Indonesia.

Runa, I. W. (2018). Arsitektur publik Bali Kuno dan sistem spasial desa pegunungan. Denpasar: Udayana University Press.

Windhu, I. B. O., dkk. (1985). Bangunan tradisional Bali serta fungsinya. Denpasar: Departemen Pendidikan dan Kebudayaan Direktorat Jenderal Kebudayaan Proyek Pengembangan Kesenian Bali. 